\title{
SOBREVIDA DEL ESTADIO PUPARIO DE COCHLIOMYIA HOMINIVORAX, EN LABORATORIO BAJO DETERMINADAS CONDICIONES DE HUMEDAD Y TEMPERATURA (SANTA FE - ARGENTINA)
}

\author{
ORCELLET, V. M. ${ }^{1}$
}

\begin{abstract}
RESUMEN
Cochliomyia hominivorax es un díptero que se comporta como parásito obligado en su etapa larvaria, causando miasis en hospedadores de sangre caliente, incluido el hombre.

Pupas de esta mosca fueron cultivadas en el laboratorio en tres temperaturas ambiente (14, $18 \mathrm{y}$ $24^{\circ} \mathrm{C}$ ) y en suelos argiudoles tipicos con tres niveles de humedad (suelo seco, capacidad de campo y suelo saturado). La emergencia de adultos es directamente proporcional al aumento de temperatura, con un minino de nacimientos del $46,66 \%$ a $14^{\circ} \mathrm{C}$ y un máximo del $96,66 \%$ a los $24^{\circ} \mathrm{C}$; exceptuando el suelo saturado, con los otros dos niveles de humedad del suelo no se observaron diferencias. Estos datos contribuyen a conocer las limitaciones en el desarrollo y viabilidad de la pupa.
\end{abstract}

Palabras clave: Cochliomyia hominivorax, pupas, viabilidad.

\section{SUMMARY}

Survival of the puppal stage of Cochliomyia Hominivorax, in laboratory under determined conditions of humidity and temperature (Santa Fe-Argentina).

Cochliomyia hominivorax is a dipteran that behaves as a mandatory parasite in its larval stage, causing myiasis in warn blood hosts, included man. This fly's pupae were cultured in the laboratory at three temperatures $\left(14,18\right.$ and $\left.24^{\circ} \mathrm{C}\right)$ and in typical argiudoles soils with three levels of humidity (dry soil, field capacity and saturated soil). Emergence of adults resulted positive to increases in temperature, with a minimum hatching of $46,66 \%$ at $14^{\circ} \mathrm{C}$ and a maximum of $96,66 \%$ at $24^{\circ} \mathrm{C}$; excepting the saturated soil, the others levels of soil humidity did not show differences. These data contribute to the knowledge the limitations in development and viability of pupae.

Key words: Cochliomyia hominivorax, pupae, viability.

1.- Cátedra de Parasitología y Enfermedades Parasitarias. Facultad de Ciencias Veterinarias, UNL. Kreder 2805. (3080) Esperanza, provincia de Santa Fe.

Manuscrito recibido el 7 de noviembre de 2005 y aceptado para su publicación el 30 de enero de 2005. 